\title{
FROM NUREMBERG TO THE HAGUE AND BEYOND: INTERNATIONAL CRIMINAL LAW IN COURTS: COURT OF BOSNIA AND HERZEGOVINA AS AN EXAMPLE
}

\author{
Manfred Dauster \\ University of Saarland, Institute for Economic Criminal Law, \\ International and European Criminal Law
}

\begin{abstract}
DAUSTER, M. From Nuremberg to The Hague and Beyond: International Criminal Law in Courts: Court of Bosnia And Herzegovina as an Example. Bratislava Law Review, Vol. 3, No. 2 (2019), pp. 76 - 83. ISSN 2585-7088, eISSN: 2644-6359
\end{abstract}

\begin{abstract}
International criminal law in courts will seize our interest forever. Adjudication of international criminal law violations have to happen in and by courts. They may be national courts; they also may be international (permanent or ad hoc) courts. Not to forget: It is also proposed to prosecute internationally active terrorists by international courts. It is worthwhile to take a short look at the historical development of such discussions. The so-called International (Legal) Community has discussed all forms of international criminal jurisdiction and will keep on discussing. In Bosnia and Herzegovina once the so-called internationals started an experiment with the (national) Court of Bosnia and Herzegovina, which in its nutshell was an administrative court that then was turned into a hybrid court predominantly for war crimes (and other serious felonies). As such a hybrid institution the Court was successful. International judges have left and the court became a purely national institution again. The short hybrid history of this court in a corner of the Western Balkans is worthwhile to be studied shortly.

Key words: genesis of humanitarian law, international criminal law, failures in institutionalizing the adjudication, genocide in Former Yugoslavia, UN-ad hoc Tribunal, making of a national War Crimes Court, Bosnia and Herzegovina.
\end{abstract}

\section{HISTORICAL RESPECTIVE}

International Criminal Law is a very young legal plant when we compare it to International Public Law, which came into existence in Europe in the $17^{\text {th }}$ century. ${ }^{1}$ For a long period of time, it was simply unthinkable to prosecute people based upon international law. Even public international law knew interactions between States only, as they were natural subjects to universal public international law, and their interactions were its source. International institutions including international courts, as we know them today were completely unknown. ${ }^{2}$ International institutions came into existence not earlier than midst $19^{\text {th }}$ century, e. g. Central Commission on Rhine Revised Shipping Traffic of

\footnotetext{
VERDROSS, A., SIMMA, B. Universelles Völkerrecht, 3. Auflage, Berlin, 1994, $\$ 25-30$.

2 However, KANT, I. Zum Ewigen Frieden. Ein philosophischer Entwurf, Königsberg 1795, Werkausgabe Band XI, herausgegeben von Wilhelm Weischedel. Frankfurt, 1964, p. 195 - 251.
} 
17 October 1868. ${ }^{3}$ The Central Rhine Commission (and Danube Commission) remained the only international institutions for a long time.

Henri Dunant's experiences in the battle of Solferino on 24 June 1859, which he published in his book "Remembrance of Solferino" (1862), resulted in the foundation of the International Committee of the Red Cross in February 1863. ${ }^{4}$ This was the background of the (First) Geneva Convention, which was signed on 22 August 1864. The First Geneva Convention marked the beginning of Humanitarian International Law, ${ }^{5}$ which is still developing up to our days. Again, existence and refining developments of Humanitarian International Law did not mandatorily include international prosecution of violations of Humanitarian International Law by in particular international institutions. When the International Committee of the Red Cross proposed international prosecution of breaches of the Geneva Convention of 1864 after the German-French War of 1870/1871 such proposals were premature and too early. They were doomed to fail. It needed further developments in substance Humanitarian International $\mathrm{Law}^{6}$ and new deterrent experiences during World War I. Article 227 to 231 of the Versailles Peace Accord ${ }^{7}$ established Germany's responsibility for World War I and urged the last German Emperor's prosecution. ${ }^{8}$ However, Emperor Wilhelm II when he was dethroned by the 1918 November Revolution in Germany had found asylum in the Netherlands where he died on 4 June 1941 and the Dutch Government did not grant his extradition. With view on other suspects falling under Article 227 to 231, the Government of the young first German Republic of Weimar was factually not in the position to comply with the Peace Agreement's demands. ${ }^{9}$ Germany's ruling class was opposed to such prosecutions and called it the "Winners' Justice". International Criminal Justice then came to a hold. The view of International Community then changed when the world experienced the atrocities of Nazi-Germany and her allies during World War II and of Japan in East Asia. By the Moscow Declaration of 31 October 1943 published on 1 November 1943 the Allies (Soviet Union, United Kingdom and United States of America) agreed on prosecuting the major war criminals of the so-called Axe-Powers by military courts. The legal foundation of such prosecution was laid down in the London Statute of 8 August 1945 and later than in the Law No. 10 of the Allied Control Council for Germany. Both instruments established the Nuremberg Military Court, fixed the rules of proceeding and established the substance law of crimes, which that Court had to adjudicate. Those instruments gave birth to modern International Criminal Law ${ }^{10}$ and

3 BGBl 1969 II p. 597. See also the European Danube Shipping Commission (Danube Shipping Act of 7 November 1857, Wien Hof- und Staatsdruckerei 1858).

4 VERDROSS, A., SIMMA, B. Universelles Völkerrecht, op. cit., $\$ 418-421$.

5 AMBOSS K. Internationales Strafrecht, 5. Auflage. München, 2018, $\$ 6$ recital 6.

6 E. g. The Hague Conventions of 1899 and of 1907 (AMBOSS K. Internationales Strafrecht, op. cit., $\$ 6$ recital 9.

7 RGBl. 1919, p. 687 and p. 1336.

8 STERN, K. Das Staatsrecht der Bundesrepublik Deutschland, Band V. München, 2000, pp. 465; MÜLLER, K. Oktroyierte Verliererjustiz nach dem Ersten Weltkrieg. In: Archiv des Völkerrechts, 39 (2001), p. 202-222; MÜLLER, K. Die Leipziger Kriegsverbrecherprozesse nach dem Ersten Weltkrieg. In: Bernd-Rüdiger Kern, Adrian Schmidt-Recla (Hrsg.): 125 Jahre Reichsgericht. Berlin, 2006, p. 249-264; WIGGENHORN, H. Leipziger Verliererjustiz: Die Kriegsverbrecherprozesse nach dem Ersten Weltkrieg (Studien zur Geschichte des Völkerrechts, Band 10), Baden-Baden, 2005.

9 The so-called Leipzig Trials tried in first and final instance by the Reichsgericht, Germany's Supreme Court of Justice, were based upon the Law on Prosecution of War Crimes of 18 December 1919 (RGBl. I 1919, 2125) and its amendments. The case management by Reichsgericht was dilatory on purpose and even the then Reichs Minister of Justice Gustav Radbruch admitted the dilatory and obstructive case treatment in his later autobiography. AMBOSS K. Internationales Strafrecht, op. cit., $₫ 6$ recital 1; MATTHÄUS, J. The Lessons of Leipzig. In: Atrocities on Trial. Hrsg.: Heberer und Matthäus, University of Nebraska, 2008.

10 WERLE, G. Völkerstrafrecht, 3. Auflage. Tübingen, 2012, recital 15. 
International Penal Justice. Nuremberg and her courtroom 600 in the court building wrote history, which affects us even today. ${ }^{11}$

Further developments towards international criminal law codifications and international criminal institutions came to a standstill when so-called Cold War broke out. Among academics and within legal institutions including those of United Nations discussions went on but did not result in feasible legal texts. All elaborations on international criminal justice, e. g. the codification of the socalled "Nuremberg Principles" remained a United Nations internum as well as a Draft Statute of an International Criminal Tribunal. New and unexpected atrocities against humanity and human beings finally caused the change. In course of the communism falling apart Socialist Federal Republic of Yugoslavia dissolved, Member Republics like Slovenia and Croatia declared their independence at the beginning of the 90ies of last century. War broke out and resulted in mass murder, genocide and other cruelties, which the World and Europe thought of having become final part of human history. Unfortunately, International Community was rather hesitant in getting involved in the conflict, in which Serb troops fought against Bosnian troops, they fought against Croat troops and all of them somehow turned against civilians. Those fights had a lot of culminations but they reached their zenith when in July of 1995 Serb troops led by their military mastermind Ratko Mladić attacked the UN-protected zone of Srebrenica and extinguished the male population there: The genocide of Srebrenica was committed. Almost at the same time in Africa, Tutsis and Hutus in Rwanda went after each other and slaughtered thousands of human beings. The cruelties grew up to such dimensions that the Security Council of United Nations had to act. Security Council Resolution no 827 of 25 May 1993created the (Ad-hoc) International Criminal Tribunal for the Former Yugoslavia (seated in The Hague in the Netherlands) and then by Resolution no 955 of 8 November 1994 the International Criminal Tribunal for Rwanda (seated in Arusha/Rwanda). Both international judicial institutions have ceased to function. Security Council by instituting those ad-hoc tribunals entered "new territories" in legal fields. Finally, a diplomatic conference in Rome accepted the so-called Rome Statute of 1 December 1998, which entered into force on 1 July 2002. This Statute created the (permanent) International Criminal Court with its seat in The Hague/Netherlands.

\section{BOSNIA AND HERZEGOVINA: A HYBRID COURT}

The International Criminal Tribunal for the Former Yugoslavia in its operations was an expensive undertaking. The annual budget in the heydays of its existence was more than 100 million US-Dollars. ${ }^{12}$ The jurisdiction was limited to severe violations of the Geneva Conventions by war criminals on the territory of former Yugoslavia. ${ }^{13}$ Thus, the Tribunal was legally not in the position to adjudicate all war crimes, which had been committed in Yugoslavia since 1991. At the beginning of the new millennium it became apparent that the institution had to last longer than originally ex-

\footnotetext{
11 E. g The Nuremberg Principles Academy describes their challenge as follows: The International Nuremberg Principles Academy (Nuremberg Academy) is dedicated to the promotion of international criminal law and human rights. It is located in Nuremberg, the birthplace of modern international criminal law. Conscious of this historic heritage, the Nuremberg Academy supports the fight against impunity for universally recognized international core crimes: genocide, crimes against humanity, war crimes and the crime of aggression.

12 ICTY-website „199Costs of Justice“.

13 Report ICTY 1993 paras. 32 in: Human Rights Law Review 1996, pp. 211.
} 
pected. UN Security Council Resolution 1503 established a so-called "completion strategy", which set up deadlines for investigations, first instance and last instance trials to be completed before the institution ceases its functions. ${ }^{14}$ In the context of discussing and drafting that "completion strategy" the question was discussed, what to do with all the other felonies having been committed in the Yugoslavian wars, which the Tribunal was not able to tackle. In order to prevent impunity, national institutions were then focused in Bosnia and Herzegovina as well as in other States, which succeeded Yugoslavia.

\subsection{In particular: The situation of Bosnia and Herzegovina}

Bosnia and Herzegovina is a small and in particular very poor country in the Western Balkans with a population of around 3.4 million people, an unemployment rate of almost $50 \%$ at the beginning of the millennium and a total gross national product of 4.6 billion US-Dollars in 1999 - a smaller product than that of a major German city. The average income of a Bosnian employee in 2000 was about $300.00 € /$ month. Along with Kosovo and Macedonia Bosnia and Herzegovina had always been one of the weak regions of Yugoslavia depending on resources from Belgrade and better doing republics like Slovenia and Croatia. The weakness did not cease by end of the war in 1995.

Since independence and in particular since the end of the war by the so-called Dayton Peace Accord in December 1995, Bosnia and Herzegovina relied on international financial aid. At the end of the 1990ies, the economic and social situation in Bosnia and Herzegovina was deplorable. The country's former socialist economy in the particular Yugoslavian form of workers' self-management on paper turned into a Western market economy. However, in bitter reality an uncontrolled black market system had been established with all negative consequences. Privatization of self-managed industry badly progressed if so, people having made fortune during the wars or having assumed political power often benefitted from such transfer from public ownership to private property.

Moreover, the Dayton Peace Accord maintained Bosnia and Herzegovina as a forth existing legal entity of Public International Law but brought to Bosnia and Herzegovina a new constitution. In terms of bringing the armed conflict within Bosnia and Herzegovina to an end this constitution is the result of compromising with every war party and therefore created a monster of institutions, authorities and jurisdictions all over the country that is unseen in Europe or on this globe elsewhere. The Dayton Constitution gave birth to two entities almost completely independent from each other and a central State, which is not disposing of any real competence or jurisdiction except defense and foreign affairs. The centralized entity of Republika Srpska with almost $48 \%$ of the territory and in population and her policy might be characterized by jealously safeguarding their jurisdiction and not having much interest in entity-to-State- and inter-entity-cooperation. This often obstructive attitude is an obstacle to national improvements. The second entity is Federation of Bosnia and Herzegovina, which is constituted by Bosniak (Muslim) and Croat components. The Federation is governed by a Federal Government and Parliament but on a sub-level by 10 cantons, again with governments and cantonal assemblies. Cooperation between the Federal level and the sub-entities is not running smoothly because Croat minorities within those cantons felt and are still feeling not to be appropriately represented within the Federal bodies.

14 AMBOSS K. Internationales Strafrecht, op. cit., par. 6 recital 15. 
When looking at the overall system, observers from abroad are struck by the fact that they have to deal about 150 ministers in 13 governments and with 13 parliamentary assemblies. ${ }^{15}$

The 1995 Dayton Constitution established a (national) Constitutional Court of Bosnia and Herzegovina but is silent about the judicial power in general. Up to now, judiciary and its power is mainly subject to Entities legislation.

\subsection{The move to the Court of Bosnia and Herzegovina}

At the end of the 1990ies and in the dawn of the "Completion Strategy" of the UN-Security Council talks among ICTY and countries concerned, inter al. with Bosnia and Herzegovina started. Along those talks ICTY already transferred pending cases from The Hague to Sarajevo (so-called 11biscases). ${ }^{16}$ The 11 bis-methodology did not work because not only Bosnia and Herzegovina but all countries concerned were not prepared for war crime prosecution in the dimension that ICTY expected them to be. When Yugoslavia fell apart, so did the criminal legal system in the region. Necessity of reforming the criminal legal system became obvious. However, in Bosnia and Herzegovina national authorities did not take the challenge serious. And again, there were unresolvable frictions: Judicial power was enshrined to the two Entities and they had to organize efficient prosecution and adjudication of war criminals as well as of other bad people, and at the end of the avenue there was the question: Could a Bosniak (Muslim) court try a Serb perpetrator, and vice versa? Anyway, among members of the International Community persuasion was growing that the country needed fundamental changes in the criminal law system not only because of imminent war crime prosecution but also in order to create an environment of legal security for foreign investments and against fraud, corruption and organized crime.

National elections in Bosnia and Herzegovina were observed by OSCE since the war had ended. As the Constitutional Court of Bosnia and Herzegovina has not the jurisdiction on deciding election complaints, OSCE requested the Office of the High Representative whose mandate was to implement the civilian aspects of the Dayton Peace Accord to provide for a judicial remedy in such and other (administrative) matters, which lied in the constitutional jurisdiction of the State of Bosnia and Herzegovina. So, the High Representative of Bosnia and Herzegovina in exercising his exceptional powers ordered on 12 November 2000 the establishment of the Court of Bosnia and Herzegovina (Decision no 50/2000). ${ }^{17}$ In 2000/2001 there was therefore a State level judicial body installed, which had the potential to become the necessary war crime adjudication institution of Bosnia and Herzegovina.

In May 2002, Lord Paddy Ashdown succeeded Wolfgang Petritsch in the office of High Representative in Sarajevo, and he was convinced that his primary challenge had to get rid of rampant organized crime. It needed many talks between him and then ICTY-Prosecutor Carla Del Ponte to convince him that war crime prosecution was equally a national and imminent challenge. Ashdown, who had a much more robust approach than his predecessor Petritsch rushed up the process of reforming the penal system of Bosnia and he simultaneously secured the (international) funding of new, more efficient judicial and prosecutorial institutions. After only six month in office, he, by uni-

15 DAUSTER, M. The Suffering Constitution of 1995: One of the Main Obstacles to the Improvement of Bosnia and Herzegovina. In: ELSA Passau: 1989 - 2009. 20 Years of ELSA-Passau e. V. Passau, 2009, pp. 71. 
lateral decision, enacted the Criminal Code of Bosnia and Herzegovina, ${ }^{18}$ the Criminal Procedure Code of Bosnia and Herzegovina ${ }^{19}$ and amended the Law on the Court of Bosnia and Herzegovina, ${ }^{20}$ so that this court could open a War Crime and an Organized Crime Department beside the existing Administrative Department and an Appeal Division. The Court (and the Prosecutor's Office of Bosnia and Herzegovina which was established in parallel) was operational in summer $2003 .^{21}$

The 2002/2003 criminal legal reforms represented the biggest achievement in years. ${ }^{22}$ The legislation of 2002/2003 was then even used as a model in other Western Balkan countries when they reformed their criminal legal system.

The Court, which is not a supreme court ${ }^{23}$ was conceptualized as a so-called hybrid court composed of national and international judges. The background of such national/international composition was that within International Community there were serious concerns whether national judges of Bosnia and Herzegovina could exercise the new State Court jurisdiction on criminal matters, in particular on war crimes. Foreign countries were invited to second qualified judges to Bosnia and Herzegovina ${ }^{24}$ where High Representative appointed them. ${ }^{25}$ They became Bosnian judges with all rights and duties and were sworn in by the High Judicial Council of Bosnia and Herzegovina, however the Council was not permitted to oversee the work of international judges in terms of disciplinary aspects. The appointment of High Representative exempted international judges from local disciplinary authority by diplomatic immunity and left it to the seconding countries to exercise their disciplinary jurisdiction on seconded nationals.

Organized Crime Division of the Court started operation first, then in 2004 the War Crime Division became effective. Respective first instance panels were composed

- Organized Crime: one international Presiding Judge and two national judges.

- War Crimes: one national Presiding Judge and two international judges

- Appellate panels were composed in same way.

Although one could expect a clash of legal cultures, the panels found their ways in applying national Bosnian criminal law not only on war crimes. The court did that smoothly and more efficiently than ever expected. ${ }^{26}$ In the meantime, the last international judge has left the court

18 Official Gazette of Bosnia and Herzegovina no 3/03

19 Official Gazette of Bosnia and Herzegovina no 3/03

20 Official Gazette of Bosnia and Herzegovina no 3/03. The amendments to the Law on the Court of Bosnia and Herzegovina were challenged constitutionally in front of the Constitutional Court of Bosnia and Herzegovina but then upheld by the court.

21 For the entire reform process, which also reshaped the Entities system see DAUSTER, M. The State Court of Bosnia and Herzegovina as Criminal Court. StrafverteidigerForum, 2006, pp. 316.

22 See DAUSTER, M. Tallying the Balance of Effects of the International Community in Bosnia and Herzegovina, December 1995 - March 2007 (Bilans djelovanja zajednice u Bosni I Hercegovini - od decembra 1995 do marta 2007). In: Fondacija Heinrich Böll, Examples of Bosnia and Herzegovina: Sustainable Concepts or Los Ways of the International Community? (Primjer Bosne I Hercegovine: Ordzivi koncepti ili stranpuice meduranodne zajednice?). Sarajevo, 2007, pp. $85-107,241$ - 262, with a critical view on the International Communities achievements in the first 12 years after Dayton.

23 DAUSTER, M. A Supreme Court for Bosnian and Herzegovina: Some Thoughts on Its Necessity (Vrhovni sud za Bosnu i Herzegovinu: razmisljanja o njegovoj neophodnosti). In: Sveske za javno pravo, 2011, pp. 4

24 Seconding countries continued to pay the international judges' salaries or they allocated funding to the International Court Registry so that this body paid salaries.

25 In 2007, the appointment jurisdiction was transferred to the High Judicial Council of Bosnia and Herzegovina.

26 IVANIŠEVIĆ, B. The War Crime Chamber in Bosnia and Herzegovina: From Hybrid to Domestic Court. International Center for Transitional Justice, 2008; Court of Bosnia and Herzegovina (by the Court President Meddzida Kreso, $10^{\text {th }}$ Anniversary of Section I for War Crimes at the Court of Bosnia and Herzegovina. Sarajevo, 2015. 
by end of 2012. ${ }^{27}$ The institution turned from a hybrid to a domestic institution and keeps on producing justice.

\section{OUTLOOK}

The Court of Bosnia and Herzegovina is still in a fragile position. So far, the court shares the fate of many other State institutions in Bosnia and Herzegovina. International funds were allocated in the court's commencement but that has become history. As of the court's efficiency it found many critics among those who dream about returning to the status quo ante. International community, in particular the Office of the High Representative, is working on an "exit strategy" for years now and does not represent real support anymore. Access to European Union is still pending so that European institutions are hindered to support this unique State institution of Bosnia and Herzegovina in case serious attacks, which the Court had experienced in the past. Those who still like the Court to vanish do not ask the question what the contribution of the Court to the country's history was about when it adjudicated war crimes in the most professional way.

\section{Bibliography:}

DAUSTER, M. A Supreme Court for Bosnian and Herzegovina: Some Thoughts on Its Necessity (Vrhovni sud za Bosnu i Herzegovinu: razmisljanja o njegovoj neophodnosti). In: Sveske za javno pravo, 2011.

DAUSTER, M. Tallying the Balance of Effects of the International Community in Bosnia and Herzegovina, December 1995 - March 2007 (Bilans djelovanja zajednice u Bosni I Hercegovini - od decembra 1995 do marta 2007). In: Fondacija Heinrich Böll, Examples of Bosnia and Herzegovina: Sustainable Concepts or Los Ways of the International Community? (Primjer Bosne I Hercegovine: Ordzivi koncepti ili stranpuice meduranodne zajednice?). Sarajevo, 2007.

DAUSTER, M. The State Court of Bosnia and Herzegovina as Criminal Court. StrafverteidigerForum, 2006.

DAUSTER, M. The Suffering Constitution of 1995: One of the Main Obstacles to the Improvement of Bosnia and Herzegovina. In: ELSA Passau: 1989 - 2009. 20 Years of ELSA-Passau e. V. Passau, 2009.

European Danube Shipping Commission (Danube Shipping Act of 7 November 1857, Wien Hof- und Staatsdruckerei 1858).

IVANIŠEVIĆ, B. The War Crime Chamber in Bosnia and Herzegovina: From Hybrid to Domestic Court. International Center for Transitional Justice, 2008; Court of Bosnia and Herzegovina (by the Court President Meddzida Kreso, $10^{\text {th }}$ Anniversary of Section I for War Crimes at the Court of Bosnia and Herzegovina. Sarajevo, 2015.

KANT, I. Zum Ewigen Frieden. Ein philosophischer Entwurf, Königsberg 1795, Werkausgabe Band XI, herausgegeben von Wilhelm Weischedel. Frankfurt, 1964.

MATTHÄUS, J. The Lessons of Leipzig. In: Atrocities on Trial. Hrsg.: Heberer und Matthäus, University of Nebraska, 2008.

MÜLLER, K. Die Leipziger Kriegsverbrecherprozesse nach dem Ersten Weltkrieg. In: Bernd-Rüdiger Kern, Adrian Schmidt-Recla (Hrsg.): 125 Jahre Reichsgericht. Berlin, 2006.

MÜLLER, K. Oktroyierte Verliererjustiz nach dem Ersten Weltkrieg. In: Archiv des Völkerrechts, 39 (2001).

Official Gazette of Bosnia and Herzegovina no 29/00.

Official Gazette of Bosnia and Herzegovina no 3/03.

27 TAUSAN, M. Bosnia Calls Time for Foreign Judges. In: Balkan Transitional Justice of 26 March 2012. 
Report ICTY 1993 paras. 32. In: Human Rights Law Review 1996.

STEINER, Ch., ADEMOVIĆ, N. Verfassung für Bosnien und Herzegowina. Kommentar, Sarajewo, 2012.

STERN, K. Das Staatsrecht der Bundesrepublik Deutschland, Band V. München, 2000.

TAUSAN, M. Bosnia Calls Time for Foreign Judges. In: Balkan Transitional Justice of 26 March 2012.

VERDROSS, A., SIMMA, B. Universelles Völkerrecht, 3. Auflage, Berlin, 1994.

WERLE, G. Völkerstrafrecht, 3. Auflage. Tübingen, 2012.

WIGGENHORN, H. Leipziger Verliererjustiz: Die Kriegsverbrecherprozesse nach dem Ersten Weltkrieg (Studien zur

Geschichte des Völkerrechts, Band 10), Baden-Baden, 2005.

\section{Contact information:}

Dr. Manfred Dauster

e-mail: Manfred.Dauster@oblg.bayern.de

Presiding Judge at the Bavarian Supreme Court/Munich and

Presiding Judge at the High Court of Appeal of Munich.

Member of the Institute for Economic Criminal Law,

International and European Criminal Law at the

University of Saarland, Saarbrücken

Hilblestraße 12

80636 München

Germany 